\title{
NATIONAL IDENTITY (NATID) FRAMEWORK IN MULTI-ETHNIC AFFILIATIONS CONSUMER MARKET: THE CASE OF MALAYSIA
}

\author{
HAMID RIZAL \\ ALESIA SIGANG GUGKANG \\ GEOFFREY H. TANAKINJAL \\ SUDIN LADA \\ Faculty of International Finance \\ Universiti Malaysia Sabah
}

\begin{abstract}
This paper examines the transferability of the national identity (NATID) framework in a multiethnic consumer market. Data were collected using heterogeneous purposive sampling from 403 respondents in Malaysia. This study exert also responds to the cross-cultural validation of measures used in international research whereby the authors assessed measurement invariance of the NATID dimensions construct using Malaysian and non-Malaysian samples. The analysis provided strong support for the factor structure, internal consistency, and discriminant validity on the transferability of the NATID framework on the Malaysian data sample. The result also suggested ethnic affiliations are a relevant unit of analysis and indicates that the relationship between the dimensions of NATID and overall national identity, varied across the three major ethnic groups. With reference to originality, this research is pioneering the adaptive etic approach to elicit inputs and to improve the transferability of the NATID framework.
\end{abstract}

Keywords: NATID, national identity, transferability, Malaysia, ethnic affiliations.

\section{Introduction}

The national identity describes a concept of collective behaviour (Balabanis, Diamantopoulus, Mueller, \& Melewar, 2001) that endorses economic ethnocentrism, segregation, and isolationism. More significantly, the notion of national identity has been suggested to hamper the international trade economy, and acceptance of foreign-made goods and services (Balabanis et al., 2001; Vida, Dmitrovic, \& Obadia, 2008).

However, the very premise of national identity, which is often used to describe similar consumer behaviour at a macro-level within one national market, is gradually being challenged, as many of the current consumer markets are becoming more fragmented and segregated (Craig \&
Douglas, 2010; Engelen \& Brettel, 2010). There has been a growing recognition in the marketing literature that many of the national markets are heterogeneous and culturally diverse (Cui, 1997; Nwankwo, Aiyeku, \& Ogbuchi, 2006). The concept of cultural diversity is an expression commonly used to describe salient coexistence of various ethnic affiliations within the one national market (Pires \& Stanton, 2000a).

Previous highlighted studies that ethnic affiliation has a significant influence on various consumer attitudinal-behavioural dispositions, and is progressively becoming an important marketing characteristic (Cui, 1997; Hui, Laroche, \& Kim, 2006; Singh, Kwon, \& Pereira, 2003). Nonetheless, despite the growing importance of both concepts in international marketing, 
relatively little attention has been paid on the linkage between national identity and ethnic dimension in cross-cultural marketing research. The objective of this study was to examine the marketing concept of national identity in a multi-ethnic consumer market. To achieve this purpose, the study examined the Keillor, Hult, Erffmeyer and Babakus (1996) national identity (NATID) framework across the three major ethnic groups in Malaysia (i.e., Malay, Chinese, and Indian). The coexistence of diverse ethnicity and growing purchasing power may be particularly relevant for the evaluation of national identity within Malaysia (Hirschman, 1987; Teo, 2011). This effort also complements Keillor et al. (1996) and Keillor and Hult (1999) that called for more studies in a wider variety of cultural settings to validate the NATID framework. Correspondingly, this study set forth to expand the understanding of how consumers within the cultural environment that differs significantly from the Western ontology that has profoundly dominated the ethnic marketing research and practices (Engelen \& Brettel, 2010). It is believed that this study would offer both scholars and marketers with better insights on the under-presented growing importance of ethnic consumers in Malaysia.

In the following section, the conceptualisation of national identity is reviewed. Building from social identity theory, the next section offers a discussion on ethnic affiliations. Using a survey from Malaysia, the third section explains the methodology used for the present study. The analysis of the results is presented in the next section. Based on these findings, this paper ends with in depth discussion, limitations, and also possibilities for future research.

\section{Literature Review}

\section{Conceptualising National Identity and NATID Dimensions}

Smith (1991) explicated that the fundamental notion of national identity pertains to (1) common myths and historical memories, (2) common legal rights and duties for all members, (3) mass public culture, and (4) common economy with territorial mobility for members. Similar commonality argument was also suggested by Clark (1990), suggesting that the concept of national identity represents a set of common socialisation, shared understanding, and aspirations, that bind the population together to the homeland.

From the cross-cultural marketing perspective, Erdogan and Uzkurt (2010) exerted that consumer sense of national identity relates to social responsibility during the product decision process. This corroborates with Shimp and Sharma (1987) who described consumer sense of national identity as an attitudinal-behavioural disposition that adamantly refuses to buy imported products and reprimands others for doing so, because buying foreign made goods would hurt the domestic economy and it is considered as unpatriotic.

According to Keillor et al. (1996), consumer perception of national identity consists of a multitude of unique dimensions. Building from other research paradigms on national identity, the authors conceptualised and developed the national identity (NATID) framework that is presuppose to measure individual degree of national identity across four dimensions of (1) belief system, (2) national heritage, (3) cultural homogeneity, and (4) ethnocentrism. For the present study, national identity was conceptualised based on these four dimensions.

The belief system provides an essential utility for decision makers and facilitates decision making by providing ready frameworks for unprecedented situations and provides answers to fundamental questions about the way the system works and the sources of human behaviour. Keillor and Hult (1999) indicated that belief systems pertains to the role of religion as a psychological bridge to the society's aggregate structure. According to Cui and Adams (2002), the belief system cultivates a person's sense of national identity by promoting cultural commonality and also as a mechanism in reducing cultural psychological tension. 
Studies suggested that consumer ethnocentrism functions as an antecedent and directly influences national identity (Balabanis et al., 2001; Shimp \& Sharma, 1987). Keillor et al. (1996) pointed out that a strong predisposition toward an ethnocentric attitude is also an indication that a particular culture has a high degree of national identity. An ethnocentric disposition pertains to that one group that believes their group to be superior in comparison to other groups. They view other groups from their own perspective and reject those that are different, while at the same time accepting those who are culturally alike (Shimp \& Sharma, 1987; Tajfel, 1982). The consumers within this classification consider that it is both inappropriate and immoral for one to buy products from other countries.

The two dimensions of national heritage and cultural homogeneity are theoretically related. National heritage describes the importance of historical figures and events in history, while cultural homogeneity concerns the uniqueness of this national heritage (Cui \& Adams, 2002; Thelen \& Honeycut, 2004). Different histories and events experienced by an individual produce different perceptions and beliefs about national heritage as a characteristic of national identity. Similarly, a strong sense of cohesion possessed in a group of individuals influences the relationship between cultural homogeneity and national identity.

\section{Social Identity Theory and the Role of Ethnic Affiliations}

There has been a significant number of studies in the extant cross-cultural marketing literature that argue on the fundamental assumption of a "country" as the appropriate unit of analysis. As Craig and Douglas (2006) pointed out, although the use of a country as the basis to define geographical boundaries of the research setting may be convenient, the use of a country may also lead to unintended consequences. Engelen and Brettel (2010) also asserted that a country may not be an adequately reliable indicator, as there are often substantial variations within a country that could be even greater than differences between countries.
The explanation on consumers' strong ethnic affiliations can be found in Tajfel and Turner's (1979) theory of social identity. The theory suggested that a person identifies himself as belonging to a social category or group (Stets $\&$ Burke, 2000). Through a process of social comparison, persons who are similar to the self are categorised with the self and are labelled the in-group; whereas, persons who differ from the self are categorised as the out-group (Tajfel, 1982). According to Tajfel and Turner (1979), opposing group interests in obtaining scarce resources will promote competition. However, it is from this overtly inter-group competition that helps to promote the intra-group morale, cohesiveness, and cooperation within group.

Building on social identity as a theoretical foundation, the present study proposed that an individual's perception of national identity is characterised by its membership in social and ethnic affiliation, each of which is influenced by a unique and specialised set of values. Previous studies on cross-cultural marketing offer credence on this notion. For instance Burton (2000) indicated that ethnic affiliation has a significant influence on consumer consumption behaviour. Holland and Gentry (1999) further suggested that consumers' perception toward the advertising stimuli differs across different ethnic affiliations. In another related studies, Jamal (2003), and Pires and Stanton (2000b) indicated a person's sense of ethnic affiliation influences his or her service encounter expectations.

\section{Method}

\section{Data Collection Procedure}

The present study used a sample of respondents from Malaysia. According to the census, the three major ethnic groups in Malaysia are the Malays, Chinese, and Indians (Malaysia Department of Statistics, 2010). The coexistence of multiculturalism contributes to cultural diversity of individuals with different beliefs, values, and customs; hence, offering a suitable setting for the present study. 
Online survey was used for data collection. The questionnaire was developed using the web based software-written in the html formatand distributed to respondents via email. The study used heterogeneous purposive sampling for sampling procedure. This method enabled researchers to achieve the study objectives, by selecting cases that were considered as informative (Saunders, Lewis \& Manhill, 2007). The survey was distributed to Malaysian respondents working in the public and private institutions in Kuala Lumpur, Malaysia. The respondents were screened to ensure that they were affiliated with the three major ethnic groups. The mailing was followed by a reminder message, and the data collection lasted for three months. Assurances were made that all responses would be confidential.

Out of the 650 online questionnaires that were distributed, 457 of the respondents replied within the specified time frame, indicating a $70 \%$ response rate. A total of 54 responses were identified as either not being affiliated with any of the three major ethnic groups or incomplete; therefore, excluded for further thus analysis, thus yielding a final sample of 403 respondents. Table 1 shows a description of the study respondents, where the majority of respondents were male $(60 \%)$, Malays $(45 \%)$, and within the range of 40 to 49 years old $(47 \%)$.

Table 1

Respondent profile $(N=403)$

\begin{tabular}{|c|c|c|c|c|c|}
\hline Variable & $(\%)$ & Frequency & Variable & $(\%)$ & Frequency \\
\hline Gender & & & Education level & & \\
\hline Male & 61 & 246 & Diploma & 6 & 24 \\
\hline Female & 39 & 157 & Undergraduate & 34 & 137 \\
\hline Ethnicity & & & Postgraduate & 60 & 242 \\
\hline Malay & 45 & 181 & Income level (RM) & & \\
\hline Chinese & 30 & 121 & Less than RM1000 & 10 & 40 \\
\hline Indian & 25 & 101 & RM1001 to 1999 & 5 & 20 \\
\hline Religion & & & RM2000 to 2999 & 16 & 65 \\
\hline Muslim & 45 & 181 & RM3000 to 3999 & 3 & 12 \\
\hline Buddhist & 26 & 105 & RM4000 to 4999 & 37 & 149 \\
\hline Hindu & 23 & 93 & RM5000 to 5999 & 11 & 44 \\
\hline Christian & 6 & 24 & RM6000 or more & 18 & 73 \\
\hline \multicolumn{6}{|l|}{ Age groups } \\
\hline 21 to 29 & 34 & 137 & & & \\
\hline 30 to 39 & 11 & 44 & & & \\
\hline 40 to 49 & 47 & 190 & & & \\
\hline 50 or more & 8 & 32 & & & \\
\hline
\end{tabular}

Note . RM = Ringgit Malaysia (average conversion rate is $1 \mathrm{USD}=\mathrm{RM} 3.2$ ) 


\section{Design and Survey Measures}

Table 2 shows the four dimensions of NATID (17-item): (1) national heritage, (2) cultural homogeneity, (3) belief system, and (4) consumer ethnocentrism. To improve the transferability of the NATID framework to the Malaysian cultural context, the present study employed Douglas and Craig's (2006) adaptive-etic approach. Specifically, the adaptive-etic approach suggested for both adaptation and incorporation of culturally specific values, which would allow better fitting of the constructs to the Malaysian cultural setting.

The present study followed this suggestion by interviewing a panel of six Malaysian academicians. The panel members were asked to provide comments on the original 17 NATID measurement items. To assure compatibility with the study context, panel members were selected based on their research expertise. Four members were from the business and marketing research domain, and two of the members were familiar with research on general social sciences. The interviews produced four new items that reflect the cultural specific values of national identity in the Malaysian context-and this resulted in a total of 21 measurement items. For example, an item "Malaysian people are proud of historical monuments, as a symbol of their civilization" was included under the national heritage, and three new items "It is a tradition for one to respect others religion and cultural values", "Common language of communication is imperative in cultivating Malaysian solidarity" and "Malaysians are equally the same regardless of their colour and creed" under the cultural homogeneity dimension.

The wording for all the items was changed into "Malaysia" to denote the study context. For instance, "One of the Malaysia's strengths is that it emphasises events of historical importance" and "Malaysian people are proud of their nationality". All the items were measured using a seven-point Likert scale ranging from (1) "disagree strongly" to (7) "agree strongly".

Table 2

Dimensions of the NATID framework

Dimensions

Present Study

(21 items)

\begin{tabular}{|c|c|c|}
\hline \multicolumn{3}{|c|}{ National Heritage } \\
\hline NH1 & Important people from the country's past are admired by people today & $\mathrm{NH}$ \\
\hline $\mathrm{NH} 2$ & $\begin{array}{l}\text { One of the Malaysian's strengths is that it emphasises events of historical } \\
\text { importance }\end{array}$ & $\mathrm{NH}$ \\
\hline NH3 & The Malaysian has a strong historical heritage & $\mathrm{NH}$ \\
\hline NH4 & $\begin{array}{l}\text { Malaysian people are proud of historical monuments, as a symbol of their } \\
\text { civilisation* }\end{array}$ & Added \\
\hline \multicolumn{3}{|c|}{ Cultural Homogeneity } \\
\hline $\mathrm{CH} 1$ & $\begin{array}{l}\text { A Malaysian possesses certain cultural attributes that other people do not } \\
\text { possess }\end{array}$ & $\mathrm{CH}$ \\
\hline $\mathrm{CH} 2$ & $\begin{array}{l}\text { Malaysians in general feel that they come from a common historical } \\
\text { background }\end{array}$ & $\mathrm{CH}$ \\
\hline
\end{tabular}




\begin{tabular}{|c|c|c|}
\hline \multicolumn{3}{|c|}{ Cultural Homogeneity } \\
\hline $\mathrm{CH} 3$ & Malaysian people are proud of their nationality & $\mathrm{CH}$ \\
\hline $\mathrm{CH} 4$ & People frequently engage in activities that identify them as Malaysian & $\mathrm{CH}$ \\
\hline $\mathrm{CH} 5$ & $\begin{array}{l}\text { A common language of communication is imperative in cultivating } \\
\text { Malaysian solidarity* }\end{array}$ & Added \\
\hline $\mathrm{CH} 6$ & It is a tradition for one to respect other religions and cultural values* & Added \\
\hline $\mathrm{CH} 7$ & All Malaysians are equally the same regardless of their colour and creed* & Added \\
\hline \multicolumn{3}{|c|}{ Belief System } \\
\hline BS1 & A specific religious philosophy is what makes a person uniquely Malaysian & BS \\
\hline BS2 & $\begin{array}{l}\text { It is impossible for an individual to be truly Malaysian without taking part } \\
\text { in some form of religious activity }\end{array}$ & BS \\
\hline BS3 & $\begin{array}{l}\text { Religious education is essential to preserve the cohesiveness of the } \\
\text { Malaysian society }\end{array}$ & $\mathrm{BS}$ \\
\hline BS4 & $\begin{array}{l}\text { A specific religious philosophy is not an important part of being Malaysian } \\
\text { (reverse-coded) }\end{array}$ & BS \\
\hline BS5 & A true Malaysian would never reject their religious beliefs & $\mathrm{BS}$ \\
\hline \multicolumn{3}{|c|}{ Consumer Ethnocentrism } \\
\hline CE1 & $\begin{array}{l}\text { We should purchase products manufactured in Malaysia instead of letting } \\
\text { other countries get rich off us }\end{array}$ & $\mathrm{CE}$ \\
\hline CE2 & It is always best to purchase Malaysian products & $\mathrm{CE}$ \\
\hline CE3 & $\begin{array}{l}\text { A Malaysian should not buy foreign products because it hurts Malaysian } \\
\text { business and causes unemployment }\end{array}$ & $\mathrm{CE}$ \\
\hline CE4 & It may cost me in the long run but I prefer to support Malaysian products & $\mathrm{CE}$ \\
\hline CE5 & Only those products that are unavailable in the Malaysia should be imported & $\mathrm{CE}$ \\
\hline
\end{tabular}

Note $. \mathrm{NH}=$ national heritage, $\mathrm{CH}=$ cultural homogeneity, $\mathrm{BS}=$ belief system, $\mathrm{CE}=$ consumer ethnocentrism . All items were measured using seven-point Likert scale, (1) strongly disagree (7) strongly agree.

\section{Measurement Invariance of NATID Dimensions}

Measurement invariance represents "whether or not, under different conditions of observing and studying phenomena, measurement operations yield measures of the same attribute" (Horn \& McArdle, 1992, p.117). Meredith (1993) has also defined measurement invariance as the parameters of a model depending on group membership. This study has employed the framework by Keillor et al. (1996) where the objective focused on measuring the degree of differences in national identity across nations.

When testing measurement invariance, classically the model fit for the data overall with fixed specific parameters has to be equal across groups, which is compared to the overall data 
model which is free to vary (Hortensius, 2012). Thereafter, if evidence supporting a measure's invariance is lacking, conclusions based on that scale are at best ambiguous and at worst erroneous (Steenkamp \& Baumgartner, 1998).
The measurement of invariance for this study consisted of a comparison between the work of Keillor et al. (1996) and this paper's objective, which understudies the Malaysian case of NATID dimensions.

Table 3

Model Comparison for Measurement of NATID Dimensions.

\begin{tabular}{ccc}
\hline & Metric Invariance & Configural Invariance \\
\hline$\chi^{2}$ & 120.9 & 225.61 \\
d.f & 89 & 113 \\
$\chi^{2}$ Differences & - & 104.71 \\
RMSEA & .042 & .045 \\
RNI & .91 & .97 \\
GFI & .88 & .91 \\
AGFI & .87 & .88 \\
RMSR & .05 & .06 \\
CFI & .99 & .99 \\
\hline
\end{tabular}

According to Murray, Gao, Kotabe, and Zhou (2007), firstly a two-group confirmatory analysis model was estimated as baseline for the said construct of the study and no cross-group factor constraint was enforced. Table 3 shows the two-group model with free factor loadings that fit the data well. According to Murray et al. (2007) the data proved that there is configural invariance between the two samples in the NATID dimensional construct.

The two group model was then analysed to test metric invariance, and to examine the factor loadings identically for each scale item between the samples. The factor loadings were forced to be equal between the Malaysia and non-Malaysia samples by Keillor et al. (1996). According to Murray et al. (2007), metric equivalence represents an increase in the degree of measurement invariance compared to the configural equivalence and this model is nested hierarchically on the baseline model.
A chi-square difference test was conducted thereafter to make comparison of the model fit data $\left(\Delta \chi^{2}=104.71, \mathrm{df}=24\right)$. The result was not significant. Thus, a conclusion was made where the two-group model of factor loading forced fit the data equally as the baseline model, which was tested earlier. Therefore according to Murray et al., (2007), it supports metric invariance and configural invariance.

The assessment of strength of relationships between the NATID dimensions and multiethnic affiliations of the consumer market in the case of Malaysia can now be conducted.

\section{Reliability and Validity}

With the additional four new items, the analysis shifted into the exploratory mode using exploratory factor analysis (EFA). This procedure had also been suggested as a viable approach in 
refitting the underlying measurement that could then be evaluated with the confirmatory factor analysis (CFA) (Gerbing \& Anderson, 1988; Gerbing \& Hamilton, 1997; Hair, Black, Babin, Anderson, \& Tatham, 2006).

The EFA was performed as an initial test on the 21 measurement items. As set forth by Hair et al. (2006), the cut-off criteria for the EFA were subjected to: (1) factor loading of larger than 0.60 on each item to indicate a high correlation of items selected, (2) discarding an item having cross-loading lower than 0.30, and (3) Cronbach alpha and item-to-total-correlation of larger than 0.70 and 0.50 , respectively.

Table 3 shows the result of the EFA on the pooled sample of 403 Malaysian respondents. Two of the original NATID items (BS4 and CE5) were deleted for failing to meet the specified criteria. As expected, our emic items of $\mathrm{NH} 4, \mathrm{CH} 5, \mathrm{CH} 6$ and $\mathrm{CH} 7$ were found to be highly correlated with NATID dimensions, respectively.

Table 4

Exploratory factor analysis $(\mathrm{N}=403)$

\begin{tabular}{lccc}
\hline Research constructs & Factor loading & Item to total correlation & Cronbach alpha \\
\hline National Heritage & & & .820 \\
\hline $\mathrm{NH} 1$ & .890 & .765 & \\
$\mathrm{NH} 2$ & .850 & .779 & \\
$\mathrm{NH} 3$ & .812 & .799 & \\
$\mathrm{NH} 4$ & .854 & .764 &
\end{tabular}

Cultural Homogeneity

$\mathrm{CH} 1$

.762

.795

$\mathrm{CH} 2$

.912

.838

$\mathrm{CH} 3$

.895

.794

CH4

.920

.837

CH5*

.815

.774

.830

.754

$\mathrm{CH} 7 *$

.873

.775

Belief System

\section{BS1}

BS2

.886

BS3

.922

BS5

.845

BS4

.532

Deleted
.821

.860

.804

751 


\begin{tabular}{lccc}
\hline Research constructs & Factor loading & Item to total correlation & Cronbach alpha \\
\hline Consumer Ethnocentrism & & & .905 \\
\hline CE1 & .857 & .823 & \\
CE2 & .940 & .918 & \\
CE3 & .831 & .778 & \\
CE4 & .867 & .756 & \\
CE5 & .593 & Deleted & \\
\hline
\end{tabular}

Note. *Added item.

As suggested by Gerbing and Hamilton (1997), the remaining 19 items were subsequently analysed using the confirmatory factor analysis (CFA). The suggested indices used for estimating the goodness-of-fit: (1) GFI and AGFI of larger than $0.8,(2)$ CFI greater than 0.9, (3) the RMSEA less than 0.1 , and (4) a ratio of $\chi^{2} / \mathrm{df}$ below 5 (Henry \& Stone, 1994; Hu \& Bentler, 1999).

The four NATID dimensions yielded a $\chi^{2}$ value of $120.9(\mathrm{df}=89)$, with $\chi^{2} / \mathrm{df}$ of 1.36 . The results of the analysis also indicated a satisfactory goodness-of-fit with the GFI, AGFI, CFI, and RMSEA producing values of $.88, .87, .98$ and .05 , respectively. All the parameter estimates were high with significant $\mathrm{t}$-values, ranging from 0.80 to 0.93 for cultural homogeneity, 0.72 to 0.93 for belief system, 0.70 to 0.95 for consumer ethnocentrism, and 0.71 to 0.76 for national heritage.

The convergent validity was measured based on (1) average variance extracted (AVE) of larger than 0.5 and (2) composite reliability (CR) of larger than 0.7 (Fornell \& Larcker, 1981; Joreskog \& Sorbon, 1989). The result showed a satisfactory convergent validity for the four dimensions, with the average variances extracted and the composite reliability (in parentheses) of 0.74 (0.89), 0.64 (0.84), 0.70 (0.82), and 0.54 $(0.70)$ for cultural homogeneity, belief system, consumer ethnocentrism, and national heritage, respectively.

An analysis of discriminant validity was performed by comparing the square root of the AVE with the square correlation of the given construct, and with any other construct, in the analysis. Discriminant validity exists if the items share more common variance with their respective construct than any variance that constructs share with other constructs (Fornell \& Larcker, 1981). Table 4 provides evidence of discriminant validity for the NATID framework. The AVE was identified to be higher than the correlation of the given construct or with any other constructs in the analysis. It was concluded that these results provide strong construct unidimensionality, internal consistency, and validity for the NATID framework with the Malaysian data sample.

Table 5

Discriminant validity of the NATID dimensions

\begin{tabular}{lllll}
\hline Construct & $\begin{array}{l}\text { Cultural } \\
\text { Homogeneity }\end{array}$ & $\begin{array}{l}\text { Belief } \\
\text { System }\end{array}$ & $\begin{array}{l}\text { Consumer } \\
\text { Ethnocentrism }\end{array}$ & $\begin{array}{l}\text { National } \\
\text { Heritage }\end{array}$ \\
\hline Cultural Homogeneity & 0.86 & & & \\
\hline
\end{tabular}

(Continued) 


\begin{tabular}{lllll}
\hline Construct & $\begin{array}{l}\text { Cultural } \\
\text { Homogeneity }\end{array}$ & $\begin{array}{l}\text { Belief } \\
\text { System }\end{array}$ & $\begin{array}{l}\text { Consumer } \\
\text { Ethnocentrism }\end{array}$ & $\begin{array}{l}\text { National } \\
\text { Heritage }\end{array}$ \\
\hline Belief System & $0.24^{* *}$ & 0.80 & & \\
Consumer Ethnocentrism & $0.28^{* *}$ & $0.15^{* *}$ & 0.83 & \\
National Heritage & $0.25^{* *}$ & $0.16^{* *}$ & $0.04^{*}$ & 0.74 \\
\hline
\end{tabular}

Notes.

1. *Correlation is significant at the 0.05 level, $* *$ Correlation is significant at the 0.01 level.

2. $(\mathrm{AVE})=\left(\right.$ sum of squared standardised loadings $\left.\mathrm{s}^{2}\right) /\left[\left(\right.\right.$ sum of squared standardised loadings $\left.{ }^{2}\right)+($ sum of indicator measurement error)]; Indicator measurement error can be calculated as 1 - (standardised loading).

3. Composite reliability $=(\text { sum of standardised loadings })^{2} /\left[(\text { sum of standardised loadings })^{2}+(\right.$ sum of indicator measurement error)]; Indicator measurement error can be calculated as 1 - (standardised loading) ${ }^{2}$.

\section{Developing Norms across Ethnic Groups}

The norms were established using the distribution of scores from the final 19 items for the three major ethnic groups in Malaysia (i.e. Malays, Chinese, and Indian) (Churchill, 1979). The distribution of scores was summarised by calculating the means and standard deviation for the group, and subsequently these norms were used for comparison between the ethnic groups.

Based on the results, these mean value for the NATID four dimensions was 17.91. The study further developed five classifications ranging from a low of "extremely weak" to a high of "extremely strong" national identity. As illustrated in Table 5, an overall score above 18.74 (two standard deviations above the mean) is considered to be "extremely strong" national identity. With the same logic, an "extremely weak" national identity is indicated by a score below 16.82. Scores within the range of 18.62 to 18.73 and 16.83 to 17.31 (half to two standard deviations of above and below the mean) are identified as "strong" and "weak", respectively. Finally, a classification of "neither strong nor weak" is for scores ranging from 17.32 to 18.61 (within the half standard deviation).

Table 6 shows the scores for the three ethnic groups used in the present study. The ethnic Malays score higher on the overall NATID four dimensions ( score $=22.13$ ), followed by the ethnic Indian (score $=18.34$ ), and Chinese (score $=17.63)$.

Table 6

Classification of Scores

\begin{tabular}{lll}
\hline Classification & $\begin{array}{l}\text { Range of score } \\
(\text { Mean }=17.91)\end{array}$ & $\begin{array}{l}\text { Deviations from mean } \\
\text { (Standard deviation, } \sigma=1.05)\end{array}$ \\
\hline Extremely strong & $\geq 18.74$ & $2 \sigma$ above mean \\
Strong & 18.62 to 18.73 & $0.5 \sigma$ to $2 \sigma$ above mean \\
Neither weak or strong & 17.32 to 18.61 & $0.5 \sigma$ above or below mean \\
Weak & 16.83 to 17.31 & $0.5 \sigma$ to $2 \sigma$ below mean \\
Extremely weak & $\leq 16.82$ & $2 \sigma$ below mean \\
\hline
\end{tabular}


Table 7

Scores Across Three Ethnic Groups

\begin{tabular}{llll}
\hline \multirow{2}{*}{ Construct } & \multicolumn{3}{c}{ Ethnicity } \\
\cline { 2 - 4 } & Malay $(\mathrm{N}=181)$ & Chinese $(\mathrm{N}=121)$ & Indian $(\mathrm{N}=101)$ \\
\hline Cultural Homogeneity & $5.68(1.37)$ & $4.87(1.49)$ & $4.68(1.61)$ \\
Belief System & $5.79(0.86)$ & $4.06(1.96)$ & $4.27(1.96)$ \\
Consumer Ethnocentrism & $4.55(1.14)$ & $3.55(1.05)$ & $3.70(0.92)$ \\
National Heritage & $6.25(0.93)$ & $5.15(1.09)$ & $5.69(1.78)$ \\
\hline Overall NATID score & $22.13(1.84)$ & $17.63(1.62)$ & $18.34(1.78)$ \\
\hline
\end{tabular}

Notes.

1. Mean scores are presented first followed by the standard deviation in parenthesis

2. The overall NATID score is the summated score for the four dimensions.

\section{Discussion}

For the purpose of assuring the reliability of the NATID framework, an assessment and improvement of the framework in new cultural settings are needed. This endeavour is necessary to validate the representativeness and to ascertain that the theoretical constructs do not vary in their meanings in different contextual settings.

The main objective was to examine the transferability of the NATID framework to the Malaysian multi-ethnic setting. The results indicated that the adaptive-etic approach significantly improves NATID transferability to the Malaysian data sample. The analysis showed that the new items have strong correlation with the study sample. This is supported by the result of psychometric scales (i.e. satisfactory factor structure, internal consistency, and construct validity).

The findings indicated that two of the original NATID items were less relevant to the Malaysian study sample. Specifically, the item that addresses the specific religious philosophy and individual perception toward imported products showed incongruence with the data sample. Perhaps, given the Malaysian multicultural society, enquiries that addresses about a specific religion may be considered contradictory to Malaysian values that endorse cultural diversity.

The study further examined the NATID framework across three major ethnic affiliations in Malaysia. The analysis showed that the notion of national identity significantly varies across ethnic affiliations. Based on the analysis, ethnic Malay consumers exhibited the highest score for the overall national identity within the NATID framework. From the norms' categorisation, the scale score for the ethnic Malays fell within the "extremely strong" category. For foreign business managers, doing business with the Malay consumers may require an adjustment in their strategies by emphasising the knowledge and respect for Malay customs and values. This inward orientation was also found to extend into the Malay consumption behaviour, as reflected by the consumer ethnocentrism and belief system. From the promotional and advertising perspectives, positioning a product with local values that reflect less foreign-ness is imperative for this ethnic segment.

The other two ethnic affiliations fell within the "neither weak nor strong" category. The results showed that both Indian and Chinese respondents have a strong emphasis on national heritage and cultural homogeneity than the 
other two dimensions of belief system and consumer ethnocentrism. This suggested that both ethnic Chinese and Indian consumers are more receptive to foreign made goods and services. Perhaps, since both of these ethnic groups also belong to a closely-knit community, consuming foreign made goods might also act as an indicator of a person's level of achievement. For the marketers, tailoring for these ethnic segments may require incorporating both ethnic and foreign values. For instance, marketers should consider employing ethnic actors for endorsement, or using the local-ethnic newspapers as a channel for advertisement.

\section{Implications}

Several implications may be drawn from this study. First, the study offered important theoretical implications on the replication and transferability of NATID framework. As noted by Douglas and Craig (2006), many constructs and measurement instruments are replication of studies, which are often conducted in one country. Therefore, they may not be adequate when tested in different cultural settings. The results further substantiated this argument. Since it was originally developed and tested on individualistic and relatively homogeneous social settings, the framework was initially less fitting with Malaysian culture values, which are predominantly collective and heterogeneous. The result, however, significantly improved after the inclusion of four cultural specific values. The ramifications of these findings are of great importance for researchers who intend to test the NATID framework in other cultural settings. As asserted by Herche, Swerson, and Verbeke (1996), the use of measurements assumed to possess etic, but are actually "pseudoetic", is a violation to cross-cultural research. By simply replicating a model to another cultural setting, a researcher may be drawing erroneous answers, which might be of no relevant value to the context of interest.

The second implication of this study highlighted issues of examining consumer variations from a micro-level. Correspondingly, this study provided support for ethnicity as a reliable unit of analysis. The results suggested that there are distinguishable perceptions of national identity across the major ethnic affiliations in Malaysia. For international business managers, the findings suggested that ethnic affiliation plays a significant role in the Malaysian consumer market. For foreign firms that plan to develop a marketing strategy, consideration on operational adjustments is necessary to account for the varying strengths that have been identified to be present across these ethnic groups. Specifically, developing a marketing programme based on "one-fits-all" for Malaysian consumers may not be feasible, since different ethnic consumers are suggested to maintain a significant degree of ethnic values.

\section{Limitations and Future Research}

Some limitations should be noted in the present study. Firstly, since the self-report scales were used to measure the study variables, it is possible that a common method bias will have affected some of the results. Secondly, though the model demonstrated satisfactory results with the data sample, it is posited that many of these measurement items were not entirely sufficient to reflect the Malaysian national identity. For that reason, identifying other cultural specific values that may offer a better fit to the Malaysian national identity are warranted in future investigations.

Thirdly, there is a possibility for the "universal cultural values" of the NATID framework to be attenuated as a result of inclusion of the new items. Therefore, future research should seek to validate this possibility using a new Malaysian data sample, and identify whether similar results can be achieved.

Fourthly, the majority of respondents were from high-income and highly educated categories. Therefore, the interpretation from this study should be used with caution since generalisations can only partially explicate the actual behaviour for each of the ethnic segments. Future research may want to extend this by using a larger sample 
to further examine each of the ethnic groups used in the present study (e.g., from low level income, and/or different geographical areas). Moreover, since this is a one-country study, it is also likely that the results may not be easily generalised with other countries.

Finally, the present study used the mean and standard deviation to establish norms across the three major ethnic groups. Future research should consider using more advance statistical methods, such as using structural equation modelling for second-order analysis.

\section{References}

Balabanis, G., Diamantopoulos, A., Mueller, D., Melewar, T. C. (2001). The impact of nationalism, patriotism and internationalism on consumer ethnocentric tendencies. Journal of International Business Studies, 32(1), 157-175.

Burton, D. (2000). Ethnicity, identity and marketing: A critical review. Journal of Marketing Management, 16(8), 853-877.

Churchill, G. A. (1979). A paradigm for developing better measures of marketing constructs. Journal of Marketing Research, 16(1), 64-73.

Clark, T. (1990). International marketing and national character: A review and proposal for an integrative theory. Journal of Marketing, 54(4), 66-79.

Craig, C. S., \& Douglas, S. P. (2006). Beyond national culture: Implications of cultural dynamics for consumer research. International Marketing Review, 23(3), 322-342.

Craig, C. S., \& Douglas, S. P. (2010). Assessing cross-cultural marketing theory and research: A commentary essay. Journal of Business Research, 64(6), 625-627.

Cui, G. (1997). Marketing strategies in a multiethnic environment. Journal of Marketing Theory and Practice, 5(1), 122-134.

Cui, C. C., \& Adams, E. I. (2002). National identity and NATID: An assessment in
Yemen. International Marketing Review, 19(6), 637-662.

Douglas, S. P., \& Craig, C. S. (2006). On improving the conceptual foundations of international marketing research. Journal of International Marketing, 14(1), 1-22.

Engelen, A., \& Brettel, M. (2010). Assessing cross-cultural marketing theory and research. Journal of Business Research, 64(5), 516-523.

Erdogan, B. Z., \& Uzkurt, C. (2010). Effects of ethnocentric tendency on consumers perception of product attitudes for foreign and domestic products. Cross Cultural Management: An International Journal, 17(4), 393-406.

Fornell, C., \& Larcker, D. F. (1981). Evaluating structural equation models with unobservable variables and measurement error. Journal of Marketing Research, 18(1), 39-50.

Gerbing, D. W., \& Anderson, J. C. (1988). An updated paradigm for scale development incorporating unidimensionality and its assessment. Journal of Marketing Research, 25(2), 186-192.

Gerbing, D. W., \& Hamilton, J. G. (1997). Viability of exploratory factor analysis as a precursor to confirmatory factor analysis. Structural Equation Modeling: A Multidisciplinary Journal, 3(1), 62-72.

Hair, J. F., Black, B., Babin, B., Anderson, R. E., \& Tatham. R. L. (2006). Multivariate data analysis (6th ed.). New Jersey: Pearson Prentice Hall.

Henry, J. W., \& Stone, R. W. (1994). A structural equation model of end-user satisfaction with a computer-based medical information system. Information Resources Management Journal, 7(3), 21-33.

Herche, J., Swenson, M. J., \& Verbeke, W. (1996). Personal selling constructs and measures: Emic versus etic approaches to cross-national research. European Journal of Marketing, 30(7), 83-97.

Hirschman, C. (1987). The meaning and measurement of ethnicity in Malaysia: An analysis of census classifications. Journal of Asian Studies, 46(3), 555582. 
Holland, J., \& Gentry, J. W. (1999). Ethnic consumer reaction to targeted marketing: A theory of intercultural accomodation. Journal of Advertising, 28(1), 65-77.

Horn, J. L., \& McArdle, J. J. (1992). A practical and theoretical guide to measurement invariance in aging research, Experimental Aging Research, 18 (Fall-Winter), 117-44.

Hortensius, L. (2012). Project for introduction to multivariate statistics: Measurement invariance.

Hu, L.-T., \& Bentler, P. M. (1999). Cutoff criteria for fit indexes in covariance structure analysis: Conventional criteria versus new alternatives. Structural Equation Modeling: A Multidisciplinary Journal, 6(1), 1-55.

Hui, M., Laroche, M., \& Kim, C. (2006). Consumption as a function of ethnic identification and acculturation. In Marketing and Multicultural Diversity (pp.53-72).C.P. Rao (Ed.).Hamsphire: Ashgate.

Jamal, A. (2003). Marketing in the multicultural world: The interplay of marketing, ethnicity and consumption. European Journal of Marketing, 37(11/12), 15991620.

Joreskog, K., \& Sorbon, D. (1989). Lisrel VII users guide. Mooresvill: Scientific Software.

Keillor, B. D., \& Hult, G. T. M. (1999). A fivecountry study of national identity: Implications for international marketing research and practice. International Marketing Review, 16(1), 65-82.

Keillor, B. D., Hult, G. T. M., Erffmeyer, R. C., \& Babakus, E. (1996). NATID: The development and application of a national identity measure for use in international marketing. Journal of International Marketing, 4(2), 57-73.

Malaysia Department of Statistics (2010). Malaysian Department of Statistics. Kuala Lumpur, Malaysia.

Meredith, W. (1993). Measurement invariance, factor analysis, and factorial invariance. Psychometrika, 58(4), 525-543.
Murrey, J. Y., Goa, G. Y., Kotabe, M., \& Nan Zhou. (2007). Assessing measurement invariance of export market orientation: A study of Chinese and non-Chinese in China. Journal of International Marketing, 15(4), 44-62.

Nwankwo, S., Aiyeku, J., \& Ogbuchi, A. (2006). The marketing challenge of multiculturalism: An exploratory study. In C. P. Rao (Ed.), Marketing and multicultural diversity (pp. 215-231). Hamsphire: Ashgate.

Pires, G., \& Stanton, J. (2000a). Ethnicity and acculturation in a culturally diverse country: Identifying ethnic markets. Journal of Multilingual and Multicultural Development, 21(1), 4257.

Pires, G., \& Stanton, J. (2000b). Marketing services to ethnic consumers in culturally diverse markets: Issues and implications. Journal of Service Marketing, 14(7), 607-618.

Saunders, M., Lewis, P., \& Thornhill, A. (2007). Research methods for business students. Tottenham Court Road, London: Prentice Hall.

Shimp, T. A., \& Sharma, S. (1987). Consumer ethnocentrism: Construction and validation of the CETSCALE. Journal of Marketing Research, 24(3), 280-289.

Singh, N., Kwon, I.-W., \& Pereira, A. (2003). Cross-cultural consumer socialisation: An exploratory study of socialisation influences across three ethnic groups. Psychology and Marketing, 20(10), 867-881.

Smith, A. D. (1991). National identity. London: Penguin Books.

Steenkamp, J. B. E. M., \& Baumgartner, Hans (1998). Assessing measurement invariance in cross-national consumer research. Journal of Consumer Research, 25(June), 78-90.

Stets, J. E., \& Burke, P. J. (2000). Identity theory and social identity theory. Social Psychology Quarterly, 63(3), 224-237.

Tajfel, H. (1982). Social psychology of intergroup relations. Annual Review of Psychology, 33, 1-39. 
Tajfel, H., \& Turner, J. (1979). An integrative theory of inter-group conflict. In W. G. Austin, \& S. Worchel. The social psychology of intergroup relations (pp. 33-47). Monterey, CA: Brooks/Cole Co.

Teo, R. (2011, May 3). Strong ringgit to give Malaysians better purchasing power. Borneo Post.
Thelen, S. T., \& Honeycut, E. D. J. (2004). Assessing national identity in Russia between generations using the national identity scale. Journal of International Marketing, 12(2), 58-81.

Vida, I., Dmitrovic, T., \& Obadia, C. (2008). The role of ethnic affiliation in consumer ethnocentrism. European Journal of Marketing, 42(3/4), 327-343. 